\title{
HLA Antigens on Colorectal Adenoma and Cancer Cells
}

\author{
Yasuo Horie, Mitsuro Chiba, Masahiro Iizuka, \\ Kiyoshi Igarashi and Osamu Masamune \\ The First Department of Internal Medicine, Akita \\ University School of Medicine, Akita 010
}

Horie, Y., Chiba, M., Iizuka, M., Igarashi, K. and Masamune, O. HLA Antigens on Colorectal Adenoma and Cancer Cells. Tohoku J. Exp. Med., 1990, 160 (4), 311-322 — HLA-DR and -ABC antigens on adenoma and cancer cells of the colon and rectum were investigated. Fifteen specimens of adenomas from 15 patients with sporadic colorectal adenoma, seven specimens of adenomas from seven patients with familial polyposis coli (FPC), and 10 specimens of cancers from 10 patients with colorectal cancer were obtained. Normal colonic mucosa far from the lesions, taken from 15 patients with sporadic adenoma or cancer, served as normal control mucosa. HLA antigens were identified using an immunoperoxidase staining method. Epithelia of all normal control mucosa $(n=15)$ expressed HLA-ABC antigens, but not HLA-DR antigens. HLA-DR antigens were expressed on $47 \%(7 / 15)$ of sporadic adenomas, $71 \%(5 / 7)$ of adenomas in FPC, and $100 \%(10 / 10)$ of cancers. The extent of HLA-DR expression on adenoma and cancer cells became broader with more severe dysplasia in adenoma, and increased undifferentiation in cancer. It also became broader with increasing mononuclear cell infiltration in both adenomas and cancers. HLA-DR antigens on adenoma and cancer cells appeared to be related to the neoplastic transformation of the epithelia, and to the mononuclear cell infiltration. Partial disappearance of HLA-ABC antigens on adenoma and cancer cells was observed in a few specimens of both adenomas and cancers. — HLA-DR antigens ; HLA-ABC antigens ; colorectal adenoma ; familial polyposis coli (adenomatosis coli); colorectal cancer

HLA-DR antigens are required for antigen-recognition of helper $\mathrm{T}$ cells and other immune regulations, and are expressed on immune competent cells such as macrophages, $\mathrm{B}$ cells and activated T cells. HLA-DR antigens, not expressed on normal colorectal epithelia, are expressed on adenoma and cancer cells (Thompson et al. 1982 ; Daar and Fabre 1983 ; Rognum et al. 1983 ; Csiba et al. 1984 ; Ghosh et al. 1986 ; Momburg et al. 1986 ; van den Ingh et al. 1987 ; Degener et al. 1988). However, the frequencies of HLA-DR expression in colorectal adenoma and cancer vary greatly from $0 \%$ to $54.1 \%$ and $13.3 \%$ to $93.5 \%$, respectively. HLA-DR antigens are induced as a result of a change in the genotype (Bishop 1985).

Received January 22, 1990 ; revision accepted for publication February 28, 1990.

Address for correspondence: Yasuo Horie, M.D., the First Department of Internal Medicine, Akita University School of Medicine, 1-1-1 Hondo, Akita 010, Japan. 
Neoplastic transformation is responsible for the genotype abnormality. Thus, it could be expected that HLA-DR antigens are expressed on the transformed cells. However, there are HLA-DR-negative as well as HLA-DR-positive malignant cells, and the detailed mechanisms of HLA-DR expression in malignant cells have not been fully elucidated.

In colorectal adenomas, the degree of dysplasia may be important in HLA-DR expression, but there have been no studies of the relationship between dysplasia and HLA-DR expression. In colorectal cancer, there have been conflicting reports (Daar and Fabre 1983 ; Rognum et al. 1983 ; Ghosh et al. 1986 ; Momburg et al. 1986 ; van den Ingh et al. 1987 ; Degener et al. 1988) regarding the extent of HLA-DR expression and its correlation with the histological differentiation of the cancer.

Cytokines, such as interferon gamma (Schwartz et al. 1985) and tumor necrosis factor (Pfizenmaier et al. 1987), that are released from lymphoid cells are known to induce HLA-DR antigens on the colonic cancer cells in vitro. Therefore, mononuclear cell infiltration, capable of releasing such cytokines in the lesion, may be related to the induction of HLA-DR antigens in the neoplastic cells. Recently, HLA-ABC antigens have been shown to be indispensable to antigenrecognition of cytotoxic $\mathrm{T}$ cells (Hui et al. 1984; Tanaka et al. 1985), and inhibition of malignant cell growth and metastasis (Hui et al. 1984 ; Tanaka et al. 1985 ; Wallich et al. 1985).

The frequency of HLA-DR expression, the relationship between HLA-DR expression and histological variables or HLA-ABC expression in colorectal adenoma and cancer were investigated in this study. Dysplasia in adenomas, differentiation in cancers and mononuclear cell infiltration in the lesions were used as histological variables. Since the progression from adenoma to cancer is extremely common in familial polyposis coli (FPC), compared to that in sporadic adenomas, it was of interest to compare HLA-DR antigens on adenoma cells and the histological variables in FPC with sporadic adenoma and cancer. We have previously reported the expression of HLA-DR antigens on adenoma cells in FPC (Horie et al. 1989), but the study lacked histological variables.

\section{Materials and Methods}

\section{Materials}

Fifteen specimens of adenomas from 15 patients (13 males and 2 females) with sporadic colorectal adenoma (Table 1), 7 specimens of adenoma from 7 patients (1 male and 6 females) with FPC (Table 2), and 10 specimens of cancer from 10 patients (5 males and 5 females) with colorectal cancer (Table 3 ) were obtained. These specimens were obtained by endoscopic biopsy $(n=17)$, endoscopic polypectomy $(n=9)$ or surgery $(n=6)$.

The age range of patients with colorectal adenoma, FPC, and colorectal cancer was 48 to 78 years (mean 62 years), 15 to 40 (mean 27 years), and from 45 to 76 (mean 60 years), respectively. Fifteen specimens from 15 patients with colorectal adenoma or cancer were obtained from macroscopically normal areas away from the lesion, and these served as 
TABLE 1. Expression of $H L A-D R$ and $-A B C$ antigens on colorectal adenoma cells

\begin{tabular}{|c|c|c|c|c|c|c|}
\hline $\begin{array}{l}\text { Case } \\
\text { No. }\end{array}$ & $\begin{array}{l}\text { Sex \& } \\
\text { age } \\
\text { (years) }\end{array}$ & $\begin{array}{l}\text { Degree of } \\
\text { dysplasia }\end{array}$ & $\begin{array}{l}\text { Growth pattern } \\
\text { of adenoma }\end{array}$ & $\begin{array}{l}\text { Mononuclear } \\
\text { cell } \\
\text { infiltration }^{\text {a) }}\end{array}$ & $\begin{array}{c}\text { HLA-DR } \\
\text { expression }^{\text {b) }}\end{array}$ & $\begin{array}{l}\text { HLA-ABC } \\
\text { expression }^{c)}\end{array}$ \\
\hline 1 & M 63 & Minimal & $\mathrm{T}$ & H & - & $\mathrm{nt}$ \\
\hline 2 & F 70 & Minimal & $\mathrm{T}$ & \# & - & \pm \\
\hline 3 & M 63 & Mild & $\mathrm{T}$ & H & - & + \\
\hline 4 & M 50 & Mild & $\mathrm{T}$ & $H$ & - & nt \\
\hline 5 & M 61 & Mild & $\mathrm{T}$ & H & - & + \\
\hline 6 & M 55 & Mild & $\mathrm{T}$ & \# & - & \pm \\
\hline 7 & M 48 & Mild & $\mathrm{T}$ & \# & - & + \\
\hline 8 & M 78 & Mild & $\mathrm{T}$ & H & + & + \\
\hline 9 & F 61 & Mild & $\mathrm{T}$ & \# & + & + \\
\hline 10 & M 61 & Mild & TV & \# & + & + \\
\hline 11 & M 66 & Mild & $\mathrm{T}$ & $H$ & H & + \\
\hline 12 & M 61 & Moderate & $\mathrm{T}$ & H & - & + \\
\hline 13 & M 69 & Moderate & TV & \# & + & + \\
\hline 14 & M 58 & Moderate & $\mathrm{T}$ & H & + & \pm \\
\hline 15 & M 63 & Moderate & $\mathrm{T}$ & \# & m & + \\
\hline
\end{tabular}

T, tubular adenoma; TV, tubulovillous adenoma.

a) + , $\#$, , indicate weak, moderate, strong mononuclear cell infiltration, respectively.

b) - , not stained in adenoma cells. $+, \mathrm{H}, \mathrm{H}$ indicate the extent of stained cells in all adenoma cells in less than $5 \%, 5$ to $30 \%$, more than $30 \%$, respectively.

c) \pm , HLA-ABC expression was not observed in certain parts of the section. +,

HLA-ABC expression was observed in all of the section.

nt, not tested.

TABLE 2. Expression of HLA-DR antigens on adenoma cells of familial polyposis coli

\begin{tabular}{|c|c|c|c|c|c|c|c|}
\hline $\begin{array}{l}\text { Case } \\
\text { No. }\end{array}$ & $\begin{array}{l}\text { Sex \& } \\
\text { age } \\
\text { (years) }\end{array}$ & $\begin{array}{l}\text { Malignant } \\
\text { change }\end{array}$ & $\begin{array}{c}\text { Approximate } \\
\text { number of } \\
\text { polyps }\end{array}$ & $\begin{array}{l}\text { Degree of } \\
\text { dysplasia }\end{array}$ & $\begin{array}{c}\text { Growth pattern } \\
\text { of adenoma }\end{array}$ & $\begin{array}{l}\text { Mononuclear } \\
\text { cell } \\
\text { infiltration }^{\text {a) }}\end{array}$ & $\begin{array}{l}\text { HLA-DR } \\
\text { expression }\end{array}$ \\
\hline 1 & F 17 & - & 150 & Minimal & $\mathrm{T}$ & \# & H \\
\hline 2 & M 15 & - & 30 & Mild & $\mathrm{T}$ & H & - \\
\hline 3 & F 31 & - & 1600 & Mild & $\mathrm{T}$ & H & - \\
\hline 4 & F 25 & Dukes A & 600 & Mild & $\mathrm{T}$ & H & + \\
\hline 5 & F 28 & Dukes C & 500 & Mild & $\mathrm{T}$ & \# & + \\
\hline 6 & F 41 & Dukes B & 700 & Mild & $\mathrm{T}$ & \# & + \\
\hline 7 & F 30 & Dukes A & 1300 & Moderate & $\mathrm{T}$ & \# & + \\
\hline
\end{tabular}

$\mathrm{T}$, tubular adenoma. tively.

a) + , H, \# indicate weak, moderate, strong mononuclear cell infiltration, respec-

b) - , not stained in adenoma cells. $\quad+, \mathrm{H}, \mathrm{m}$ indicate the extent of stained cells in all adenoma cells in less than $5 \%, 5$ to $30 \%$, more than $30 \%$, respectively. 
TABLE 3. Expression of $H L A-D R$ and $-A B C$ antigens on colorectal cancer cells

\begin{tabular}{|c|c|c|c|c|c|c|c|}
\hline $\begin{array}{l}\text { Case } \\
\text { No. }\end{array}$ & $\begin{array}{l}\text { Sex \& } \\
\text { age } \\
\text { (years) }\end{array}$ & $\begin{array}{c}\mathrm{CEA} \\
(\mathrm{ng} / \mathrm{ml})\end{array}$ & $\begin{array}{l}\text { Dukes' } \\
\text { stage }\end{array}$ & $\begin{array}{c}\text { Degree of } \\
\text { differentiation }\end{array}$ & $\begin{array}{c}\text { Mononuclear } \\
\text { cell } \\
\text { infiltration }\end{array}$ & $\begin{array}{l}\text { HLA-DR } \\
\text { expression }^{c)}\end{array}$ & $\begin{array}{l}\text { HLA-ABC } \\
\text { expression }^{\text {d) }}\end{array}$ \\
\hline 1 & M 63 & 7.6 & A & W & H & + & + \\
\hline 2 & M 58 & 6.0 & A & W & H & H & + \\
\hline 3 & $\mathrm{~F} 61$ & 4.2 & $\mathrm{C}$ & $\mathrm{W}$ & m & H & + \\
\hline 4 & F 34 & 1.6 & A & M & + & + & + \\
\hline 5 & F 56 & 18.1 & C & M & \# & + & t \\
\hline 6 & F 45 & 6.7 & $\mathrm{C}$ & M & H & H & + \\
\hline 7 & M 73 & 0.6 & A & $\mathrm{M}$ & \# & H & \pm \\
\hline 8 & F 74 & 2.0 & A & M & \# & \# & + \\
\hline 9 & M 61 & 3.4 & A & M & \# & m & + \\
\hline 10 & M 76 & 3.0 & B & $\mathrm{P}$ & \# & \# & + \\
\hline
\end{tabular}
tively.

${ }^{a)} \mathrm{W}, \mathrm{M}, \mathrm{P}$ indicate well, moderately, poorly differentiated adenocarcinoma, respectively.

b) $+, \mathrm{H}, \mathrm{H}$ indicate weak, moderate, strong mononuclear cell infiltration, respec-

c) $+, H, \ldots$ indicate the extent of stained cells in all cancer cells in less than $5 \%$,

5 to $30 \%$, more than $30 \%$, respectively.

d) \pm , HLA-ABC expression was not observed in certain parts of the section. +,

HLA-ABC expression was observed in all of the sections.

controls.

The degree of dysplasia was judged by the classification proposed by Muto et al. (Muto et al. 1975; Muto 1979) (Tables 1 and 2). The histological growth patterns and the degree of mononuclear cell infiltration in adenomas are presented in Tables 1 and 2 . The degree of mononuclear cell infiltration in the sections was classified as weak $(+)$, moderate $(\#)$, or strong ( $\mathrm{H})$. Malignant changes of the adenomas, and the approximate number of polyps in the colon are presented in Table 2.

The serum CEA value, Dukes' stage, degree of differentiation and degree of mononuclear cell infiltration of cancers are presented in Table 3. Histological differentiation of colorectal cancer was classified into three categories: well, moderately, and poorly differentiated adenocarcinomas, based on the General Rules for Clinical and Pathological Studies on Cancer of Colon, Rectum and Anus (1985).

\section{Immunoperoxidase staining}

HLA-DR and -ABC antigens on intestinal epithelia, including neoplastic cells, were identified by an indirect immunoperoxidase staining method. Tissue fixation, tissue mounting, and immunoperoxidase staining were performed as previously described (Chiba et al. 1986). Briefly, tissue pieces were fixed with periodate lysine- $4 \%$ paraformaldehyde, and $6 \mu \mathrm{m}$ serial frozen sections were subsequently made. Three mouse monoclonal antibodies against class I and class II antigens were applied as the first antibody. Anti-HLADR (IgG2a; Becton-Dickinson, Mountain View, CA, USA) (Wang et al. 1983) and Nu-Ia (IgG1 ; Nichirei, Tokyo) (Matsumoto 1984) were used as the anti-HLA-DR antibody, and anti-HLA-ABC (IgG1, Cappel, Cochranville, PN, USA) (Lampson and Fisher 1985) was used as the anti-HLA-ABC antibody. Two monoclonal antibodies against anti-keyhole limpet hemocyanin, clone $\times 39(\mathrm{IgG} 2 \mathrm{a})$ and $\times 40$ (IgG1) (Becton-Dickinson, Mountain 
View, CA, USA), were used as monoclonal controls. Peroxidase-labeled anti-mouse Ig (Dako, Copenhagen, Denmark) was used as the second antibody. Methyl green (0.1\%) was used for nuclear staining after the diaminobenzidine reaction. One serial section, which was stained in the absence of the first antibody, served as a control. Another section, which was stained with hematoxylin and eosin ( $\mathrm{HE})$, was used for the evaluation of dysplasia, histological differentiation and the degree of mononuclear cell infiltration.

The photographs of adenoma and cancer cells, stained with anti-HLA-DR antigens, were classified into four categories. Unstained adenoma and cancer cells were classed as negative (-), while stained adenoma and cancer cells were classed as,$+ \#$, or $\#$ with the proportion of stained cells being less than $5 \%, 5$ to $30 \%$, or more than $30 \%$, respectively. When an initial examination failed to detect HLA-DR antigens on adenoma and cancer cells, another section was made and retested.

The photographs of adenoma and cancer cells, stained with anti-HLA-ABC antigens, were classified into two categories. Complete staining and partial staining were expressed as + and \pm , respectively.

\section{Results}

Epithelia of the control sections, either without the first antibody or with monoclonal controls, were unstained. Expression of the HLA-DR antigens on adenoma and cancer cells, using either of the two antibodies, was consistent. The epithelia of the 15 control specimens expressed HLA-ABC antigens but not HLA-DR antigens. All results from the colorectal adenoma and cancer specimens are presented in Tables 1, 2 and 3 .

In the following sections 2) and 3), adenoma refers to both sporadic adenomas and FPC adenomas.

\section{Frequency of $H L A-D R$ expression}

Epithelia of sporadic colorectal adenomas, FPC adenomas and colorectal cancers were stained with anti-HLA-DR antibody in 7 of 15 specimens $(47 \%), 5$ of 7 specimens $(71 \%)$ and all of 10 specimens $(100 \%)$, respectively (Fig. 1$)$. In adenomas, the apex was weakly stained (Fig. 2). In cancers, two different

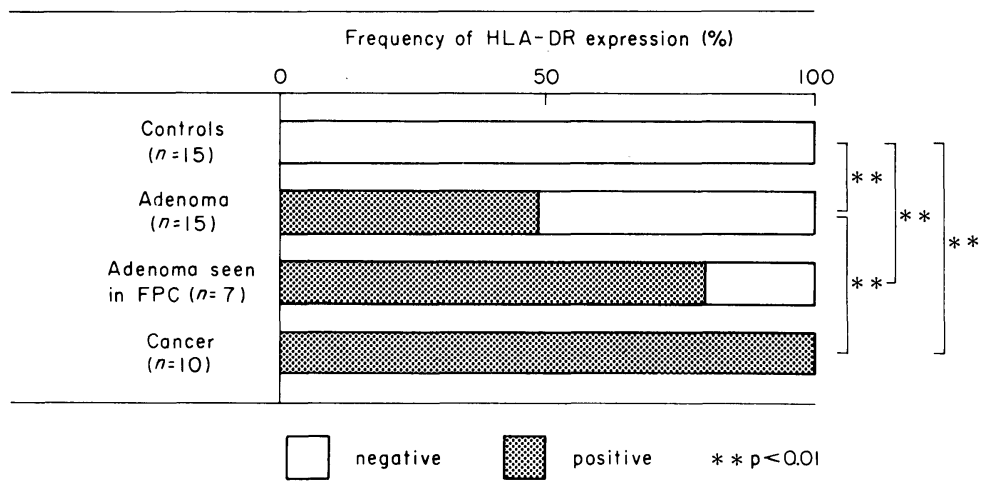

Fig. 1. Frequency of HLA-DR expression in controls, adenomas and cancers. n, number of cases. 

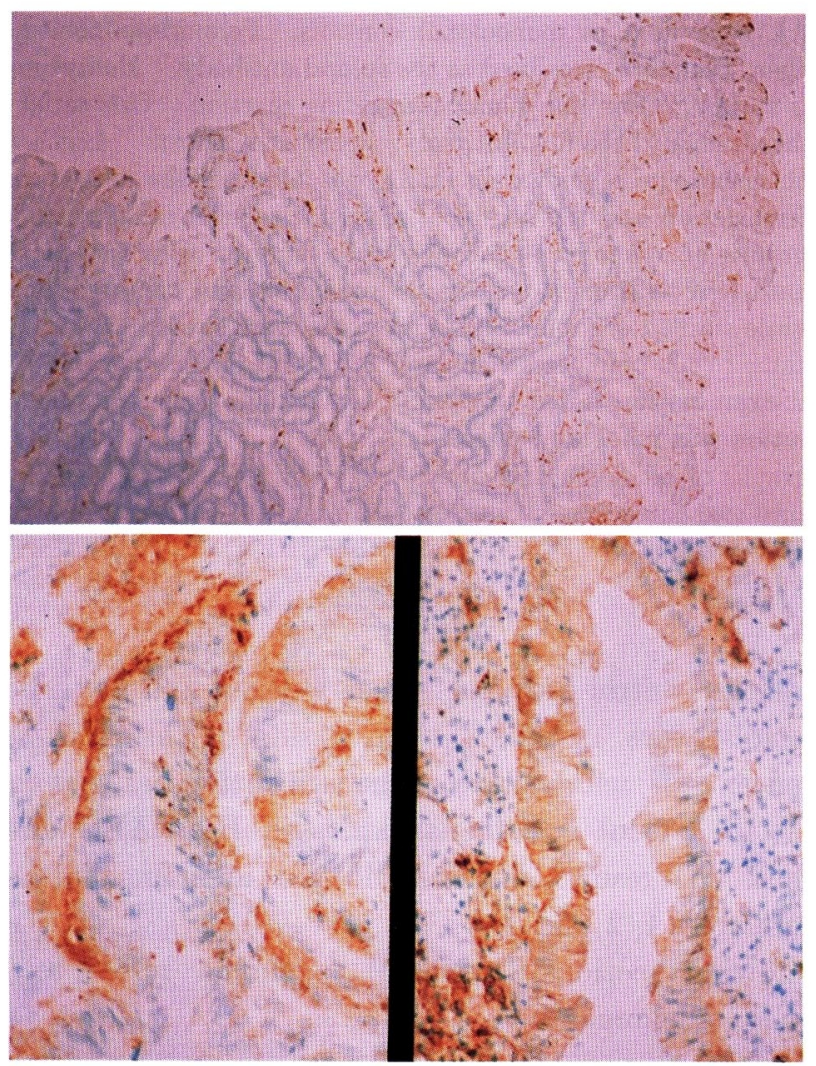

Fig. 2 (upper). Colorectal adenoma stained with Nu-Ia antibody. HLA-DR antigens on adenoma cells are weakly stained at the apex of the polyp $(\times 10)$.

Fig. 3 (lower). Two staining patterns of HLA-DR antigens in colonic cancer. HLA-DR antigens are scattered in cancer cells towards the basement membrane (left, $\times 64$ ), and expressed uniformly in the cytoplasm (right, $\times 64$ ).

patterns of HLA-DR antigens staining were observed. One, which was more common, was a strong, scattered stain towards the basement membrane (Fig. 3, left), and the other was a uniform stain in the cytoplasm (Fig. 3, right). In general, the staining intensity with the anti-HLA-DR antibody was stronger in colorectal cancers than in adenomas (Figs. 2 and 3 ).

Relationship between the degree of dysplasia of adenomas, or the degree of differentiation of cancers, and the extent of $H L A-D R$ expression

The extent of staining with the anti-HLA-DR antibody was correlated with either the degree of dysplasia of adenoma or the degree of differentiation of cancer. With more severe dysplasia or with increased undifferentiation, the adenoma and cancer cells were stained more broadly (Fig. 4). 


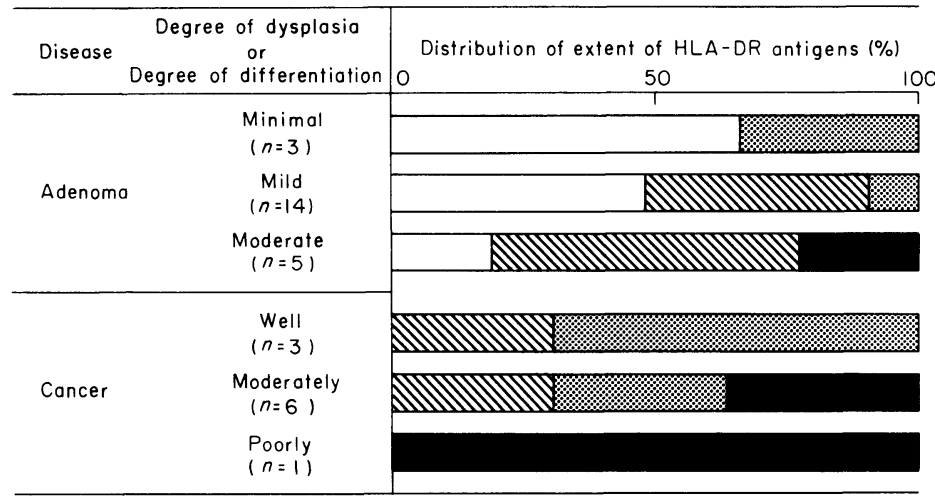

The extent of HLA-DR antigens stained in odenoma or cancer cells

\begin{tabular}{|c|c|c|}
\hline one & $<5 \%$ & $5 \sim 30 \%$ \\
\hline
\end{tabular}

Fig. 4. HLA-DR expression and the degree of dysplasia of adenomas, or degree of differentiation of cancers. $n$, number of cases.

Relationship between the degree of mononuclear cell infiltration and the extent of HLA-DR expression

The extent of the anti-HLA-DR antibody staining on adenoma and cancer cells was correlated with the degree of mononuclear cell infiltration in the lesions of colorectal adenoma or cancer. As mononuclear cell infiltration increased, the extent of staining with anti-HLA-DR antibody became broader (Fig. 5).

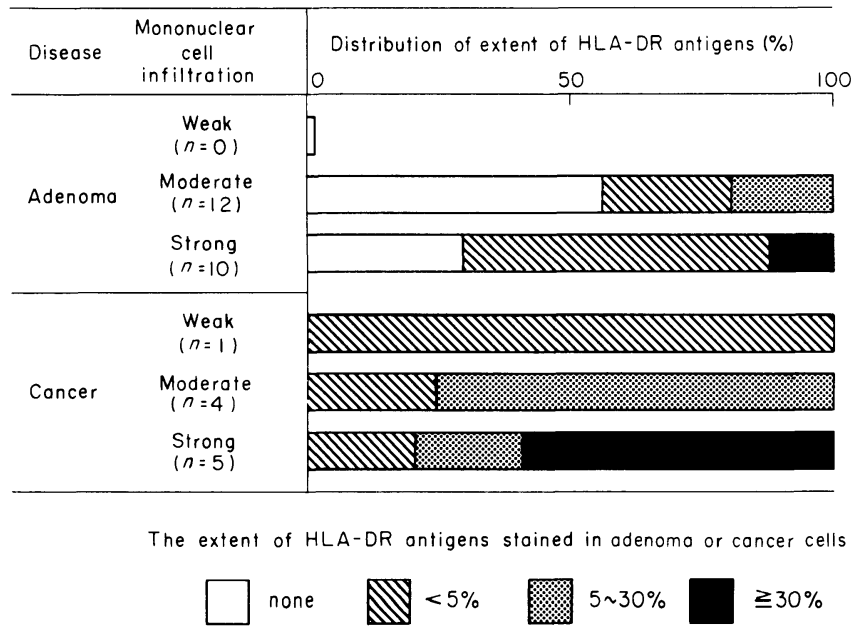

Fig. 5. HLA-DR expression and mononuclear cell infiltration in the lesion of the colorectal adenoma or cancer. $n$, number of cases. 


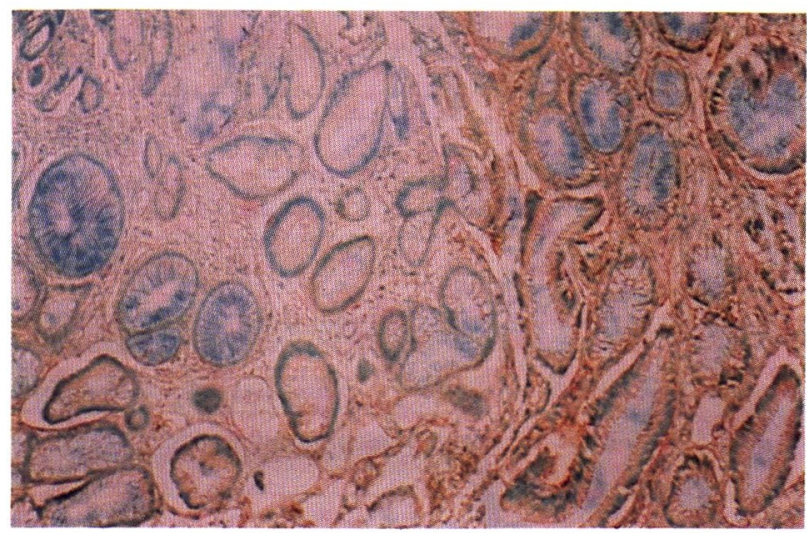

Fig. 6. Colorectal adenoma stained with HLA-ABC antibody $(\times 25)$. HLA$\mathrm{ABC}$ antigens are not expressed on adenoma cells in the crypts of the left field $(\times 25)$.

Relationship between other factors and the extent of $H L A-D R$ expression

In FPC adenomas, there was no correlation between the extent of staining with anti-HLA-DR antibody and either the presence of cancer or the number of polyps. In cancers, the extent of staining was not correlated with the serum CEA or Dukes' stage (Tables 2 and 3).

\section{$H L A-A B C$ expression}

Partial disappearance of HLA-ABC antigens on adenomas and cancers was observed in three adenoma specimens (each specimen showed minimal, mild or moderate dysplasia) (Fig. 6), and in one specimen of cancer (moderately differentiated adenocarcinoma).

\section{Discussion}

In this study, HLA-DR antigens were expressed in $47 \%(7 / 15)$ of sporadic adenomas, $71 \%(5 / 7)$ of FPC adenomas, and 100\% (10/10) of colorectal cancers. There have been only a few reports (Thompson et al. 1982 ; van den Ingh et al. 1987 ; Degener et al. 1988) of HLA-DR antigens on adenoma cells. Thompson et al. (1982) could not detect HLA-DR antigens on adenoma cells, and van den Ingh et al. (1987) detected HLA-DR antigens in only one of 12 specimens $(8.3 \%)$. Degener et al. (1988) detected HLA-DR antigens in 20 of 37 specimens $(54.1 \%$ ) (Table 4). Since Csiba et al. (1984) and Ghosh et al. (1986) dealt with only a few adenomas specimens, their results were not included in Table 4. In our study, the frequency of HLA-DR expression of sporadic adenomas was 47\% (7/15). There have been eight reports (Thompson et al. 1982 ; Daar and Fabre 1983; Rognum et al. 1983 ; Csiba et al. 1984 ; Ghosh et al. 1986 ; Momburg et al. 1986 ; van den 
TABLE 4. Expression of $H L A-D R$ antigens on human colorectal cancer and adenoma cells

\begin{tabular}{|c|c|c|c|c|c|c|}
\hline \multirow{2}{*}{ Investigator } & & \multirow{2}{*}{$\begin{array}{l}\text { Cancer } \\
\text { or } \\
\text { adenoma }\end{array}$} & \multirow{2}{*}{$\begin{array}{l}\text { Number of } \\
\text { cases }\end{array}$} & \multirow{2}{*}{$\begin{array}{c}\text { Frequency of HLA- } \\
\text { DR expression } \\
(\%)\end{array}$} & \multicolumn{2}{|c|}{$\begin{array}{l}\text { Methods to detect } \\
\text { HLA-DR antigens }\end{array}$} \\
\hline & & & & & $\begin{array}{l}\text { Monoclonal } \\
\text { antibody }\end{array}$ & Staining \\
\hline \multirow[t]{2}{*}{ Thompson et al. ${ }^{21)}$} & 1982 & Cancer & 9 & 77.8 & WI691-13-17 & IP \\
\hline & & Adenoma & 5 & 0 & WI691-13-17 & IP \\
\hline Daar \& Fabre ${ }^{5)}$ & 1983 & Cancer & 15 & 46.7 & NFK-1 & IP \\
\hline Rognum et al. ${ }^{18)}$ & 1983 & Cancer & 31 & 93.5 & HLA-DR & IF \\
\hline Csiba et al.4) & 1984 & Cancer & 15 & 13.3 & TDR31.1 & IP \\
\hline Ghosh et al. ${ }^{7)}$ & 1986 & Cancer & 32 & 71.9 & DA6-147 etc. & IP \\
\hline Momburg et al. ${ }^{14)}$ & 1986 & Cancer & 100 & 42.0 & 2.06 & IP \\
\hline \multirow[t]{2}{*}{ Ingh et al. ${ }^{22)}$} & 1987 & Cancer & 20 & 30.0 & Q5/13 & IP \\
\hline & & Adenoma & 12 & 8.3 & Q5/13 & IP \\
\hline \multirow[t]{2}{*}{ Degener et al. ${ }^{6)}$} & 1988 & Cancer & 123 & 50.4 & ISCR & IP \\
\hline & & Adenoma & 37 & 54.1 & ISCR & IP \\
\hline
\end{tabular}

IP, immunoperoxidase method; IF, immunofluorescence method.

Ingh et al. 1987 ; Degener et al. 1988) of HLA-DR antigens on cancer cells, and the frequencies of HLA-DR antigens on cancer cells varied greatly from $13.3 \%$ to $93.5 \%$ (Table 4 ). In our study, the frequencies of HLA-DR expression were high in sporadic adenomas, and highest in colorectal cancers. The reason for the very high frequencies in this study might be due to the use of more sensitive antiHLA-DR antibodies (Nu-Ia and anti-HLA-DR monoclonal antibody), and the reexamination of new sections when the initial examination failed to detect HLA-DR antigens on adenoma and cancer cells.

In FPC adenomas, the frequency of HLA-DR expression was intermediate between sporadic adenomas and cancers. It is well known that FPC adenomas invariably become malignant at an early age. This indicates that FPC adenomas may be more able to progress to cancers than can sporadic adenomas. The frequency of HLA-DR expression appeared to be closely related to the neoplastic transformation of the epithelia.

In adenomas, including both sporadic and FPC, the extent of HLA-DR expression tended to be broader with increasing degree of dysplasia. To our knowledge, this is the first report detailing the relationship between HLA-DR expression on adenoma cells and the degree of dysplasia in adenoma. In colorectal cancers, there have been conflicting reports (Daar and Fabre 1983 ; Rognum et al. 1983 ; Ghosh et al. 1986 ; Momburg et al. 1986; van den Ingh et al. 1987 ; Degener et al. 1988) regarding the correlation between the extent of staining with anti-HLA-DR antibody and the histological differentiation of cancer cells. In this study, the extent of HLA-DR expression tended to broaden with increased 
undifferentiation.

The staining intensity with anti-HLA-DR antibody on adenoma and cancer cells was generally stronger in cancers than in adenomas.

These results indicate that HLA-DR antigens on adenoma and cancer cells were quantitatively and qualitatively related to the neoplastic transformation of the epithelia, and appeared to precede or coincide with the neoplastic changes in the epithelia.

In this study, the extent of HLA-DR expression on adenoma and cancer cells increased as mononuclear cell infiltration in the lesions increased in both adenomas and cancers. This indicates that HLA-DR antigens on adenoma and cancer cells may be related to local mononuclear cell infiltration, as well as to the neoplastic change of the epithelia. The association between HLA-DR antigens on cancer cells and infiltrated lymphocytes in the lesions was suggested from the fact that interferon gamma (Carrel et al. 1985; Schwartz et al. 1985), tumor necrosis factor (Pfizenmaier et al. 1987), and other unknown agents produced by human lymphocytes (Groenewegen et al. 1986) have the ability to induce expression of HLA-DR antigens on various human cell lines, including human colon cancer cell lines.

The partial disappearance of HLA-ABC antigens on adenoma and cancer cells was observed in three of 13 adenomas $(23 \%)$ and one of 10 cancers $(10 \%)$ in this study (Tables 1 and 3). Disappearance of HLA-ABC antigens has been reported in colorectal cancer (Momburg et al. 1986), and may be related to the growth and metastasis of malignant cells (Hui et al. 1984; Tanaka et al. 1985; Wallich et al. 1985). To our knowledge, this is the first report describing the loss of HLA-ABC antigens on adenoma cells. Although Momburg et al. (1986) reported a correlation between undifferentiated cancer and a loss of HLA-ABC antigens, such a correlation was not observed in our study.

\section{Acknowledgments}

We wish to thank Miss Chizuko Igarashi for her skillful preparation of this manuscript, and Miss Yuki Sato for her assistance to this experiment.

This work was partly supported by a grant from the Research Committee for Intractable Intestinal Diseases (Member; Osamu Masamune), the Ministry of Welfare, Japan.

\section{References}

1) Bishop, J.M. (1985) Viral oncogenes. Cell, 42, 23-38.

2) Carrel, S., Schmidt-Kessen, A. \& Giuffré, L. (1985) Recombinant interferon- $\gamma$ can induce the expression of HLA-DR and -DC on DR-negative melanoma cells and enhance the expression of HLA-ABC and tumor-associated antigens. Eur. J. Immunol., 15, 118-123.

3) Chiba, M., Ohta, H., Nagasaki, A., Arakawa, H. \& Masamune, O. (1986) Lymphoid cell subsets in normal human small intestine. Gastroenterol. Jpn., 21, 336-343.

4) Csiba, A., Whitwell, H.L. \& Moore, M. (1984) Distribution of histocompatibility and leukocyte differentiation antigens in normal human colon and in benign and malig- 
nant colonic neoplasms. $\quad B r . J$. Cancer, 50, 699-709.

5) Daar, A.S. \& Fabre, J.W. (1983) The membrane antigens of human colorectal cancer cells: Demonstration with monoclonal antibodies of heterogeneity within and between tumours and of anomalous expression of HLA-DR. Eur. J. Cancer Clin. Oncol., 19, 209-220.

6) Degener, T., Momburg, F. \& Moller, P. (1988) Differential expression of HLA-DR, HLA-DP, HLA-DQ and associated invariant chain ( $\mathrm{Ii}$ in normal colorectal mucosa, adenoma and carcinoma. Virchows Arch. [A], 412, 315-322.

7) Ghosh, A.K., Moore, M., Street, A.J., Howat, J.M.T. \& Schofield, P.F. (1986) Expression of HLA-D subregion products on human colorectal carcinoma. Int. J. Cancer, 38, 459-464.

8) Groenewegen, G., De Ley, M., Jeunhomme, G.M.A.A. \& Buurman, W.A. (1986) Supernatants of human leukocytes contain mediator, different from interferon $\gamma$, which induces expression of MHC class II antigens. J. Exp. Med., 164, 131-143.

9) Horie, Y., Chiba, M., Iizuka, M., Igarashi, K. \& Masamune, O. (1989) Colonic lymphoid cell subsets and epithelial HLA-DR antigens in familial polyposis coli. Gastroenterol. Jpn., 24, 632-639.

10) Hui, K., Grosveld, F. \& Festenstein, H. (1984) Rejection of transplantable AKR leukemia cells following MHC DNA-mediated cell transformation. Nature, 311, 750752.

11) Japanese Research Society for Cancer of Colon and Rectum (1985) General Rules for Clinical and Pathological Studies on Cancer of Colon, Rectum and Anus. 4th ed., Kanehara Shuppan, Tokyo. (Japanese)

12) Lampson, L.A. \& Fisher, C.A. (1985) Immunoblot specificity of monoclonal antibodies assayed against complex extracts. Anal. Biochem., 144, 55-64.

13) Matsumoto, K. (1984) Studies of monoclonal antibodies specific to human leukocyte differentiation antigens. J. Kurume Med. Assoc., 47, 1382-1397. (Japanese)

14) Momburg, F., Degener, T., Bacchus, E., Moldenhauer, G., Hammerling, G. \& Moller, P. (1986) Loss of HLA-A, B, C and de novo expression of HLA-D in colorectal cancer. Int. J. Cancer, 37, 179-184.

15) Muto, T. (1979) Colon polyps. The Pathological and Clinical Study. First ed., Nankodo, Tokyo. (Japanese)

16) Muto, T., Bussey, H.J.R. \& Morson, B.C. (1975) The evaluation of cancer of the colon and rectum. Cancer, 36, 2251-2270.

17) Pfizenmaier, K., Scheurich, P. \& Schluter, C. (1987) Tumor necrosis factor enhances HLA-A, B, C and HLA-DR gene expression in human tumor cells. J. Immunol., 138, 975-980.

18) Rognum, T.O., Brandtzaeg, P. \& Thorud, E. (1983) Is heterogenous expression of HLA-DR antigens and CEA along with DNA-profile variations evidence of phenotypic instability and clonal proliferation in human large bowel carcinomas? Br. J. Cancer, 48, 543-551.

19) Schwartz, R., Momburg, F., Moldenhauer, G., Dorken, B. \& Schirrmacher, V. (1985) Induction of HLA class-II antigen expression on human carcinoma cell lines by INF-gamma. Int. J. Cancer, 35, 245-250.

20) Tanaka, K., Isselbacher, K.J., Khoury, G. \& Jay, G. (1985) Reversal of oncogenesis by the expression of a major histocompatibility complex class I gene. Science, 228, 26-30.

21) Thompson, J.J., Herlyn, M.F., Elder, D.E., Clark, W.H., Steplewski, Z. \& Koprowski, H. (1982) Expression of DR antigens in freshly frozen human tumors. Hybridoma, 1, 161-168.

22) van den Ingh, H.F., Ruiter, D.J., Griffioen, G., van Muijen, G.N.P. \& Ferrone, S. (1987) HLA antigens in colorectal tumors - Low expression of HLA class I antigens in mucinous colorectal carcinomas. $B r . J$. Cancer, 55, 125-130. 
23) Wallich, R., Bulbuc, N., Hammerling, G.J., Katzav, S., Segal, S. \& Feldman, M. (1985) Abrogation of metastatic properties of tumour cells by de novo expression of $\mathrm{H}-2 \mathrm{~K}$ antigens following H-2 gene transfection. Nature, 315, 301-305.

24) Wang, C.Y., Al-Katib, A., Lane, C.L., Koziner, B. \& Fu, S.M. (1983) Induction of HLA-DC/DS (Leu 10) antigen expression by human precursor B cell lines. J. Exp. Med., 158, 1757-1762. 